\title{
Investigation on Thermal Conductivity of Vanadium Titano-magnetite Concentrate Carbon-containing Pellets in Direct Reduction
}

\author{
Shao-li $Y A N G^{1, a}$, Rong-jian PAN ${ }^{1, b}$, Lan $\mathrm{MA}^{2, c}$, Jun-han $\mathrm{LI}^{2,}$, , Hong $\mathrm{LI}^{3, \text { e }}$ \\ ${ }^{1}$ Panzhihua University, Panzhihua 617000, China \\ ${ }^{2}$ Sichuan Technology Engineering Research Center for Vanadium \& Titanium Materials, Panzhihua \\ 617000, China) \\ ayangsls|@163.com, ${ }^{b}$ haoyunjiuzhe2008@126.com, ${ }^{c}$ hudie5656@163.com, ${ }^{d}$ \\ 276228290@qq.com \\ e 353386825@qq.com
}

\begin{abstract}
Keywords: vanadium titano-magnetite concentrate; carbon-containing pellets; direct reduction; thermal conductivity
\end{abstract}

Abstract. In this paper, internal heat transfer process of vanadium titano-magnetite concentrate carbon-containing pellets was analyzed in direct reduction at different temperatures. The thermal conductivity of vanadium-titanium magnetite carbon-containing pellets at different temperatures were determined under the condition of optimal process parameters taken from previous works. XRD was used to examine the phases of various products at different temperatures in direct reduction. Experimental results revealed that change in thermal conductivity of vanadium titano-magnetite concentrate was roughly the same as the common iron ore concentrate. The measured values of the thermal conductivity were consistent with the changing trend of the theoretical thermal conductivity. The thermal conductivity change within $0.06 \sim 0.12 \mathrm{~W} / \mathrm{m}^{\circ} \mathrm{C}$ in the temperature range of $300^{\circ} \mathrm{C}-1150^{\circ} \mathrm{C}$. The thermal conductivity increase very rapidly when temperature exceeds $1000^{\circ} \mathrm{C}$.

Vanadium titano-magnetite is an important ore, which contains diverse rare metals, such as vanadium, titanium, and iron and so on. Therefore, it is essential to know, how to make use of these ore. Traditionally, blast furnace was used to smelt vanadium titano-magnetite. Recently, the rapid development of direct reduction process formed enormous new direct reduction process, such as Fastmet, Krupp-Codir, and Comet and so on, because the flaw of blast furnace affects both economical and environment aspects ${ }^{[1-5]}$. Vanadium titano-magnetite concentrate is used to smelt hot metal and titanium slag. Vanadium titano-magnetite concentrate carbon-containing pellet for iron making is one of the new processes for smelting vanadium titano-magnetite concentrate. So far, a number of works for the study of vanadium titano-magnetite concentrate carbon-containing pellets for iron making were conducted by researchers all over the world ${ }^{[6-8]}$. It is said that vanadium titano-magnetite in China is different from other countries, and it is extremely hard to deal with this kind ore ${ }^{[9,10]}$. According to enormous investigation on vanadium titano-magnetite concentrate, carbon-containing pellets were studied by numerous researchers in china, and it was found that almost all of them focused on investigation of direct reduction of the vanadium tiano-magnetite concentrate ${ }^{[11-13]}$. However, the investigation on thermal conductivity of vanadium titano-magnetite concentrate carbon-containing was not conducted by them. And it is extremely important to understand the internal heat transfer of pellets with the variation of external circumstances. Therefore, it is very important to improve parameters of process in valid time.

The heat transfer performance of vanadium titano-magnetite carbon-containing pellets in direct reduction is represented by its thermal conductivity. So, in this paper, internal heat transfer process of vanadium titano-magnetite carbon-containing pellets was analyzed, and experiments for determining thermal conductivity of vanadium-titanium magnetite carbon-containing pellets at different temperature were conducted. After the experimental and theoretical analysis, change law of thermal conductivity for vanadium titano-magnetite carbon-containing pellets in direct reduction was acquired. 


\section{Experiment}

\section{Raw materials}

Vanadium titano-magnetite (provided by Huili in Sichuan Province, China) was used as raw materials. The chemical composition and particle sizes of the raw materials are given in Table 1 and Table 2, respectively. PVA and bituminous coal were used as the binder and reductant, respectively. The chemical compositions and particle sizes of PVA and bituminous coal are given in Table 3 and Table 4, respectively. Testing samples were composed of vanadium titano-magnetite, PVA, and bituminous coal.

Table 1 The chemical compositions of vanadium titano-magnetite concentrate (wt\%)

\begin{tabular}{ccccccccccccc}
\hline $\mathrm{TFe}$ & $\mathrm{FeO}$ & $\mathrm{Fe}_{2} \mathrm{O}_{3}$ & $\mathrm{TiO}_{2}$ & $\mathrm{~V}_{2} \mathrm{O}_{5}$ & $\mathrm{SiO}_{2}$ & $\mathrm{Al}_{2} \mathrm{O}_{3}$ & $\mathrm{~S}$ & $\mathrm{CaO}$ & $\mathrm{MgO}$ & $\mathrm{P}$ & $\mathrm{As}$ & $\mathrm{Cr}_{2} \mathrm{O}_{3}$ \\
\hline 56.00 & 23.49 & 54.51 & 10.50 & 0.58 & 3.83 & 1.83 & 0.257 & 2.263 & 2.292 & 0.018 & 0.01 & 0.42 \\
\hline
\end{tabular}

Table 2 Particle sizes of vanadium titano-magnetite concentrate

\begin{tabular}{|c|c|c|c|c|c|}
\hline Size/mesh & +80 & $-80 \sim+100$ & $-100 \sim+120$ & $-120 \sim+200$ & -200 \\
\hline wt $\%$ & 3.60 & 2.21 & 4.72 & 23.94 & 65.5 \\
\hline \multicolumn{6}{|c|}{ Table 3 The chemical compositions of pulverized coal (wt\%) } \\
\hline \multicolumn{2}{|c|}{ Fixed carbon } & Volatiles & Sulphfur & \multicolumn{2}{|c|}{ Heat $\left(\mathrm{KJ} \cdot \mathrm{Kg}^{-1}\right)$} \\
\hline \multicolumn{2}{|c|}{79.33} & 10.62 & 0.69 & \multicolumn{2}{|c|}{28511} \\
\hline \multicolumn{6}{|c|}{ Table 4 Particle sizes of pulverized coal } \\
\hline \multicolumn{2}{|c|}{ Size/mesh } & +60 & $-60 \sim+80$ & $-80 \sim+100$ & -100 \\
\hline \multicolumn{2}{|l|}{ wt $\%$} & 2.55 & 21.67 & 3.07 & 72.71 \\
\hline
\end{tabular}

\section{Experiment apparatus}

Figure 1 shows the test system for thermal conductivity of the sample in this study.

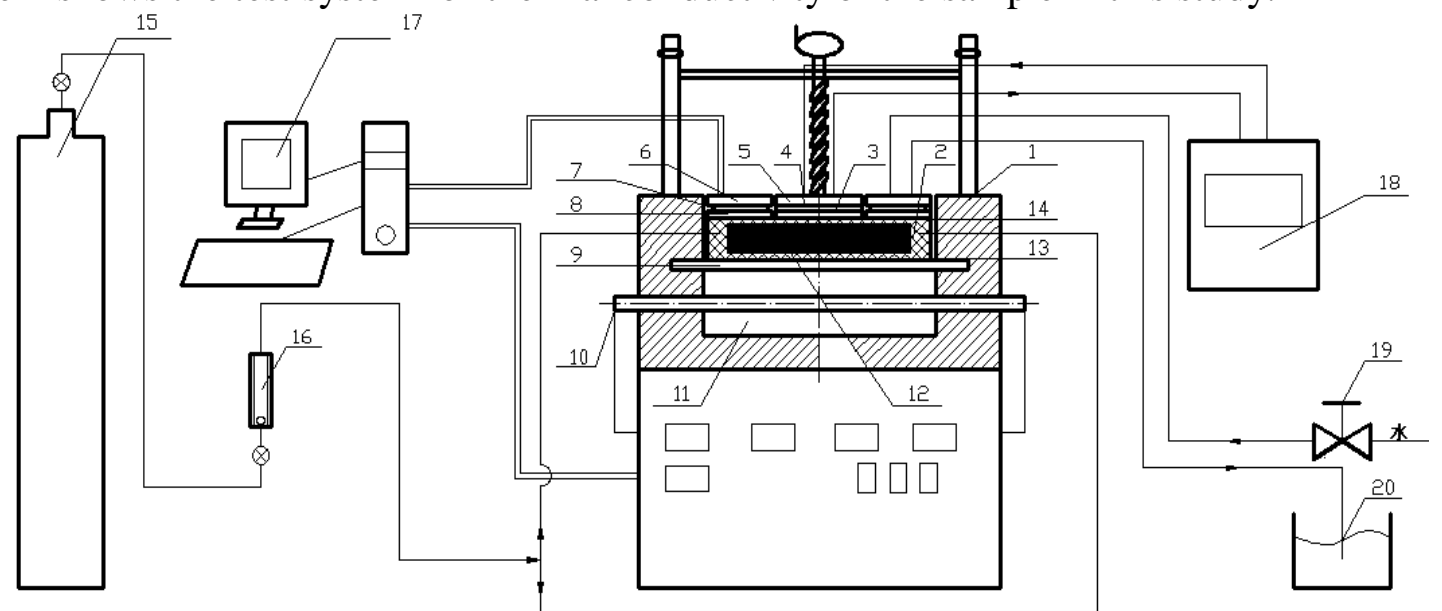

Fig. 1 Test system for thermal conductivity of the sample in this study

1-Insulation of furnace body; 2-Thermal insulating blanket; 3-Calorimetric board; 4-Heat flow meter;

5-Calorimetric water bath; 6-Guarded hot water bath; 7-Semiconductor refrigeration piece; 8-Heat shield panel; 9-Hot plate; 10-Heater element; 11-Furnace; 12-A specimen; 13-Hot face thermocouple; 14-Cold face thermocouple; 15 -a cylinder for protection of atmosphere; 16-a flowmeter; 17-Computer real-time online control; 18-Thermoalstatic bath; 19-Control valve for water flow; 20-A flume 


\section{Experimental procedure}

\section{Sample preparation}

Process parameter in this experiment is one of the optimal process parameters, and the process parameter has been chosen from previous work ${ }^{[14]}$. Vanadium titano-magnetite concentrate obtained by drying, grinding and sieving. Pulverized coal was weighed according to the mass ratio of 4:1. Vanadium titano-magnetite concentrate and Pulverized coal were mixed well. Then, adding proper amount of binder PVA with concentration of $10 \%$ and water to the mixture. The amount of PVA and water which were added to the mixture were calculated according to the formulas [1] and [2]. The ratio of raw material is given in Table 5. After mixing the raw materials, bulk samples were obtained by DDJ-50 type electro-hydraulic system at pressure of 10Mpa. Moreover, the sample were put into drying cabinet for drying under isothermal condition of $120^{\circ} \mathrm{C}$ for 4 hours. After drying, the weight and thickness of the sample was measured. Finally, the sample was putted into the DRS-III type thermal conductivity tester in order to test its comprehensive thermal conductivity.

$$
\begin{gathered}
M_{P V A}=\left(M_{O}+M_{C}\right) \bullet W_{P V A} / C_{P V A} \\
M_{H_{2} O}=\left(M_{O}+M_{C}\right) \bullet W_{H_{2} O}-M_{P V A}+M_{P V A} / C_{P V A}
\end{gathered}
$$

Where, $\mathrm{M}_{\mathrm{PVA}}$ is the mass of PVA, $\mathrm{g} ; \mathrm{M}_{\mathrm{O}}$ is the mass of vanadium titano-magnetite concentrate, $\mathrm{g}$; $\mathrm{M}_{\mathrm{C}}$ is the mass of coal, $\mathrm{g}$; $\mathrm{M}_{\mathrm{PVA}}$ is the mass of PVA, $\mathrm{g}$; $\mathrm{M}_{\mathrm{H} 2 \mathrm{O}}$ is the mass of $\mathrm{H}_{2} \mathrm{O}, \mathrm{g}$; and $\mathrm{C}_{\mathrm{PVA}}$ is the concentration of PVA, \%.

Table 5 The ratio of raw materials

\begin{tabular}{cccccc}
\hline $\begin{array}{c}\text { V Ti-magnetite } \\
\text { concentrate }(\mathrm{g})\end{array}$ & $\begin{array}{c}\text { Pulverized } \\
\text { coal }(\mathrm{g})\end{array}$ & $\begin{array}{c}\text { Water }\left(\mathrm{W}_{\mathrm{PVA}}\right) \\
(\mathrm{wt} \%)\end{array}$ & Extra water $(\mathrm{g})$ & $\begin{array}{c}\text { Binder }\left(\mathrm{W}_{\mathrm{PVA}}\right) \\
(\mathrm{wt} \%)\end{array}$ & $\begin{array}{c}\text { Binder } \\
(\mathrm{g})\end{array}$ \\
\hline 2000 & 500 & $8 \%$ & 87.5 & $0.5 \%$ & 125 \\
\hline
\end{tabular}

Testing for thermal conductivity of sample

There is not a facility used for testing the pellet's thermal conductivity. However, according to reference [15], it can be concluded that, with the same ratio of the raw materials, and external circumstance, diverse shapes of samples have the same thermal conductivity. Therefore, spherical sample was replaced by bulk sample in this experiment as shown in Figure 2.

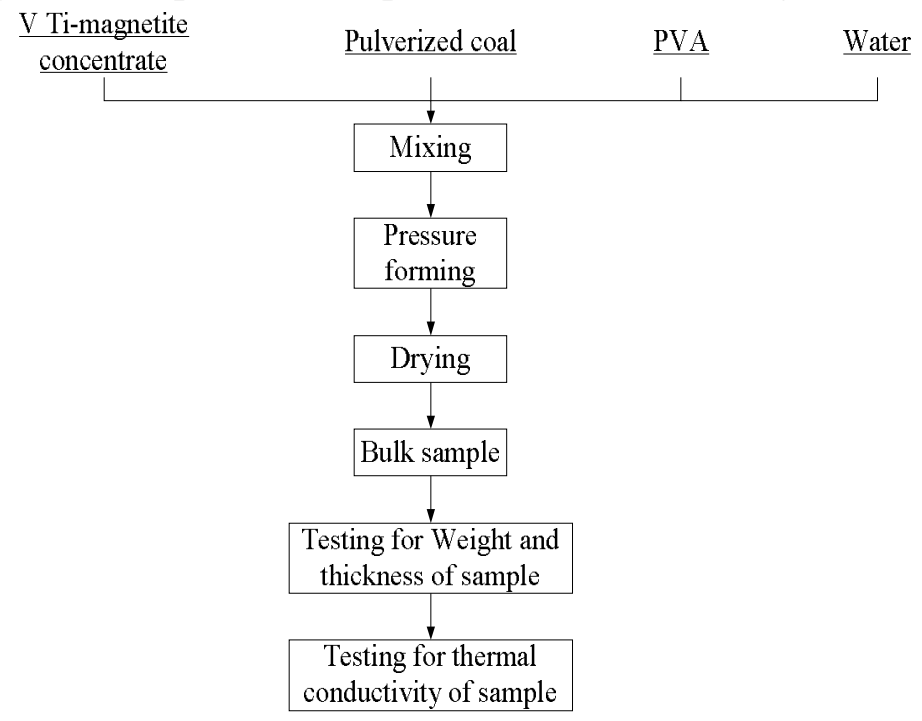

Fig.2 The experimental procedure in this study

\section{Results and Discussion}

\section{Results}

The diverse thermal conductivities of the sample with variation of temperature were obtained by experiment, which were repeated three times. Figure 3 shows the relationship between the diverse 
thermal conductivities of the sample and variation of temperature and results of three sets of repeated experiments were obtained. And errors among the three times repeated experiments were indexed by using error bars, as shown in Figure 3.

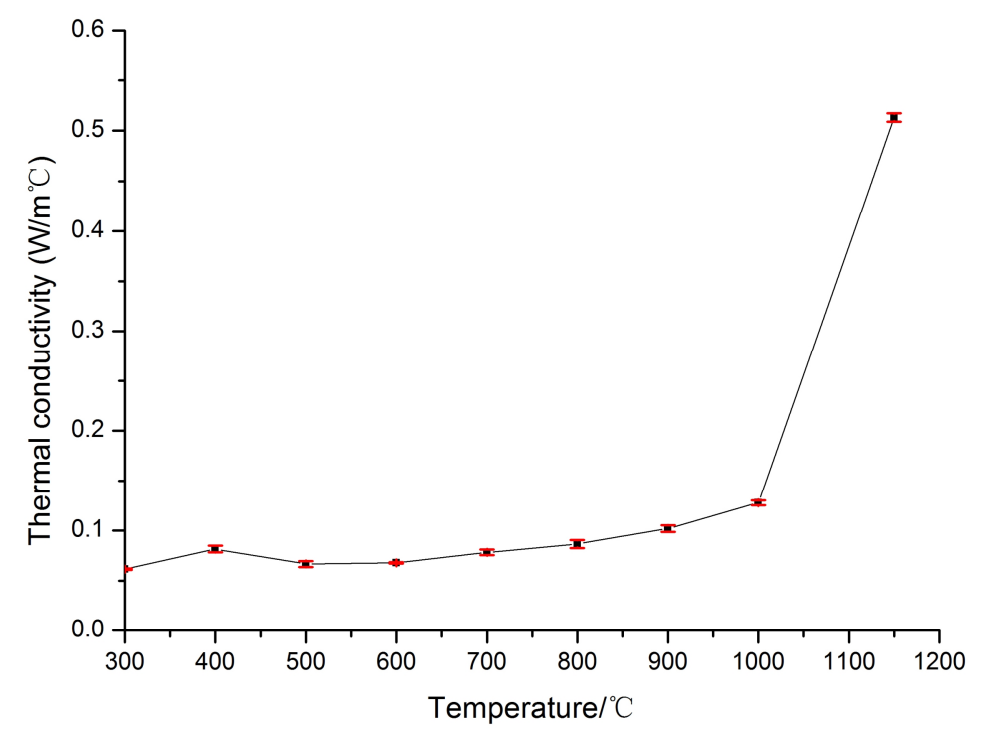

Fig.3 The relationship between diverse thermal conductivities of the sample and variation of temperature

\section{Discussion}

The change trend of thermal conductivity of common iron ore concentrate

The main direction reduction of iron oxides by coal are shown in Table 7 . When temperature is lower than $570^{\circ} \mathrm{C}$, the reduction of iron oxides conforms to formulas (2) and (3). When the temperature is higher than $570^{\circ} \mathrm{C}$, the reduction of iron oxides conforms to formulas (2), (3) and (4). Part of carbon oxides released from both the volatile and chemical reactions with iron ore, react with carbon in the coal to produce more carbon monoxide via the Boudouard reaction (1). The phase equilibrium diagram of iron oxides reduced by coal is shown in Figure 4.

Table 6 thermodynamics on reduction of iron oxides by coal ${ }^{[16]}$

\begin{tabular}{ccc}
\hline Numbers & Reactions & $\triangle \mathrm{G}^{\theta}(\mathrm{J} / \mathrm{mol})$ \\
\hline$(1)$ & $\mathrm{C}+\mathrm{CO}_{2}=\mathrm{CO}$ & $170700-174.5 \mathrm{~T}$ \\
$(2)$ & $\mathrm{Fe}_{2} \mathrm{O}_{3}+\mathrm{CO}=2 \mathrm{Fe}_{3} \mathrm{O}_{4}+\mathrm{CO}_{2}$ & $-52131-41 \mathrm{~T}$ \\
$(3)$ & $1 / 4 \mathrm{Fe}_{3} \mathrm{O}_{4}+\mathrm{CO}=3 / 4 \mathrm{Fe}+\mathrm{CO}_{2}$ & $-9832+8.58 \mathrm{~T}$ \\
$(4)$ & $\mathrm{Fe}_{3} \mathrm{O}_{4}+\mathrm{CO}=3 \mathrm{FeO}+\mathrm{CO}_{2}$ & $35380-40.16 \mathrm{~T}$ \\
$(5)$ & $\mathrm{FeO}+\mathrm{CO}=\mathrm{Fe}+\mathrm{CO}_{2}$ & $-22800+24.26 \mathrm{~T}$ \\
\hline
\end{tabular}




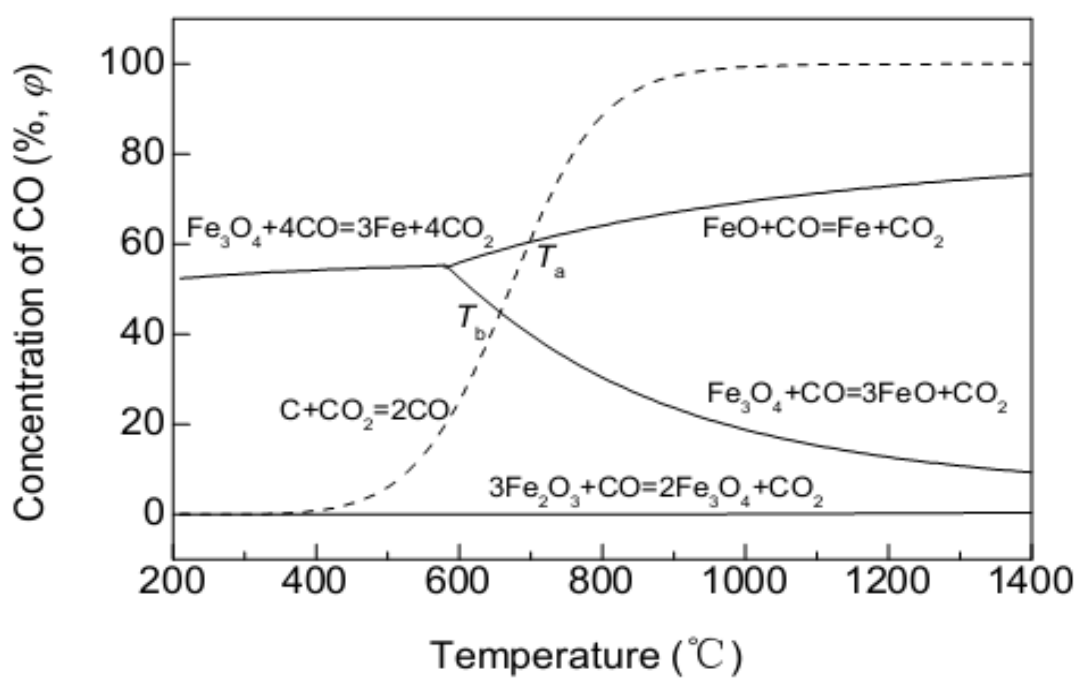

Fig. 4 Phase equilibrium diagram of iron oxides reduced by coal

So, direct reduction of the common iron ore concentrate will go through direct reduction of four stages as follows:

$$
\mathrm{Fe}_{2} \mathrm{O}_{3} \rightarrow \mathrm{Fe}_{3} \mathrm{O}_{4} \rightarrow \mathrm{FeO} \rightarrow \mathrm{Fe}
$$

Effects of varying temperature on thermal conductivity of metallic iron and iron-oxides can be seen from the Figure $5^{[17,18]}$, and it may be deduced as follows:

(1) Different iron-oxides have different thermal conductivity.

(2) The thermal conductivity of iron-oxides decline over time with increasing temperature.

(3) The metallic iron of thermal conductivity is far beyond the iron-oxides.

(4) The total thermal conductivity increase over time with the direct reduction of iron ore concentrate proceeding.

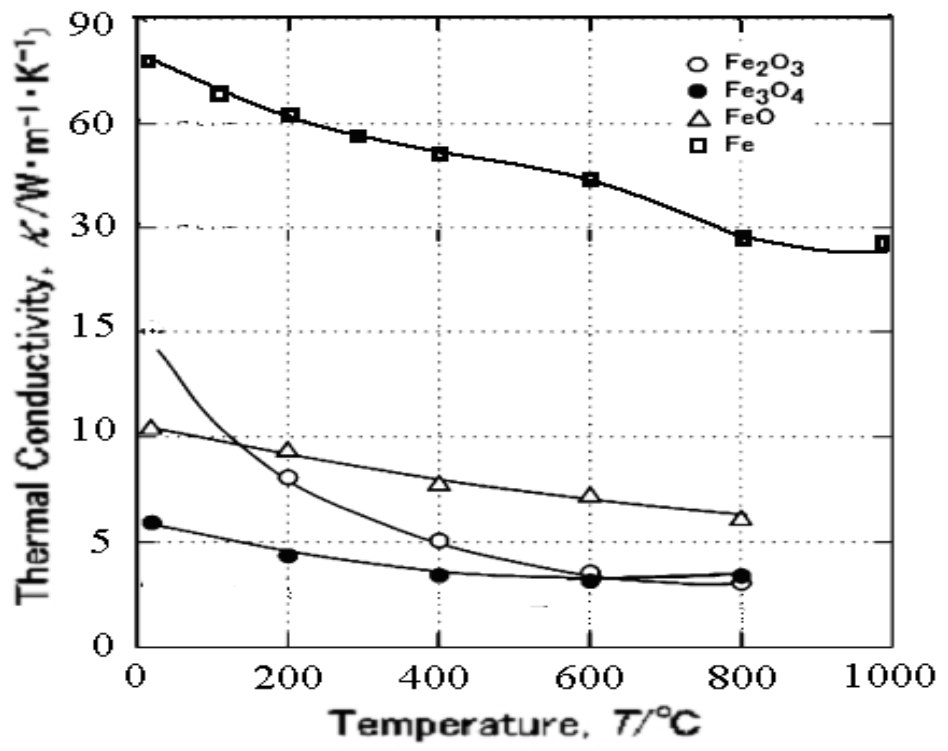

Fig.5 Effects of varying temperature on thermal conductivity of metallic iron and iron-oxides

The change trend of thermal conductivity of vanadium titano-magnetite concentrate

Direct reduction progress of vanadium titano-magnetite concentrate is mainly combined two steps of direct reduction progress which contains the reduction of the iron oxides and iron-titanium oxides. The main reduction of iron oxides is the same as direct reduction of the common iron ore concentrate. The main reduction of iron-titanium oxides by $\mathrm{C}$ and $\mathrm{CO}$ is shown in Table 8 and Table 9, respectively. Figure 6 shows the $\triangle G^{\theta}$ of the iron oxides and ilmenite reduced by $C$ with increasing temperature. Figure 7 shows the Phase equilibrium diagram of iron oxides and ilmenite reduced by CO. 
Table 8 Thermodynamics on reduction of ilmenite by $\mathbf{C}^{[10]}$

\begin{tabular}{ccc}
\hline Numbers & Reaction & $\triangle \mathrm{G}^{\theta}(\mathrm{J} / \mathrm{mol})$ \\
\hline$(6)$ & $\mathrm{FeTiO}_{3}+\mathrm{C}=\mathrm{Fe}+\mathrm{TiO}_{2}+\mathrm{CO}$ & $190900-161 \mathrm{~T}$ \\
$(7)$ & $3 / 4 \mathrm{FeTiO}_{3}+\mathrm{C}=3 / 4 \mathrm{Fe}+1 / 4 \mathrm{Ti}_{3} \mathrm{O}_{5}+\mathrm{CO}$ & $209000-168 \mathrm{~T}$ \\
$(8)$ & $2 / 3 \mathrm{FeTiO}_{3}+\mathrm{C}=2 / 3 \mathrm{Fe}+1 / 3 \mathrm{Ti}_{2} \mathrm{O}_{3}+\mathrm{CO}$ & $213000-171 \mathrm{~T}$ \\
$(9)$ & $1 / 2 \mathrm{FeTiO}_{3}+\mathrm{C}=1 / 2 \mathrm{Fe}+1 / 2 \mathrm{TiO}+\mathrm{CO}$ & $252600-177 \mathrm{~T}$ \\
$(10)$ & $2 \mathrm{FeTiO}_{3}+\mathrm{C}=\mathrm{Fe}+\mathrm{FeTi} \mathrm{O}_{5}+\mathrm{CO}$ & $185000-155 \mathrm{~T}$ \\
$(11)$ & $1 / 4 \mathrm{FeTiO}_{3}+\mathrm{C}=1 / 4 \mathrm{Fe}+1 / 4 \mathrm{TiC}+\mathrm{CO}$ & $182500-127 \mathrm{~T}$ \\
$(12)$ & $1 / 3 \mathrm{FeTiO}_{3}+\mathrm{C}=1 / 3 \mathrm{Fe}+1 / 3 \mathrm{Ti}+\mathrm{CO}$ & $304600-173 \mathrm{~T}$ \\
\hline
\end{tabular}

Table 9 Thermodynamics on reduction of ilmenite by $\mathrm{CO}^{[18]}$

\begin{tabular}{ccc}
\hline Numbers & Reaction & $\triangle \mathrm{G}^{\theta}(\mathrm{J} / \mathrm{mol})$ \\
\hline$(13)$ & $\mathrm{Fe}_{2} \mathrm{TiO}_{5}+\mathrm{CO}=\mathrm{Fe}_{2} \mathrm{TiO}_{4}+\mathrm{CO}_{2}$ & $-141097-20.79 \mathrm{~T}$ \\
$(14)$ & $\mathrm{Fe}_{2} \mathrm{TiO}_{5}+2 \mathrm{CO}=\mathrm{Fe}+\mathrm{FeTiO}_{3}+\mathrm{CO}_{2}$ & $-59997+6.51 \mathrm{~T}$ \\
$(15)$ & $\mathrm{Fe}_{2} \mathrm{TiO}_{4}+\mathrm{CO}=\mathrm{Fe}+\mathrm{FeTiO}_{3}+\mathrm{CO}_{2}$ & $-18900+27.3 \mathrm{~T}$ \\
$(16)$ & $2 \mathrm{FeTiO}_{3}+\mathrm{CO}=\mathrm{FeTi}_{2} \mathrm{O}_{5}+\mathrm{Fe}+\mathrm{CO}_{2}$ & $1306.2+17.136 \mathrm{~T}$ \\
$(17)$ & $\mathrm{FeTiO}_{3}+\mathrm{CO}=\mathrm{TiO}_{2}+\mathrm{Fe}+\mathrm{CO}_{2}$ & $21892+1.192 \mathrm{~T}$ \\
$(18)$ & $3 / 5 \mathrm{FeTi}_{2} \mathrm{O}_{5}+\mathrm{CO}=2 / 5 \mathrm{Ti}_{3} \mathrm{O}_{5}+3 / 5 \mathrm{Fe}+\mathrm{CO}_{2}$ & $45162.6+0.386 \mathrm{~T}$ \\
\hline
\end{tabular}

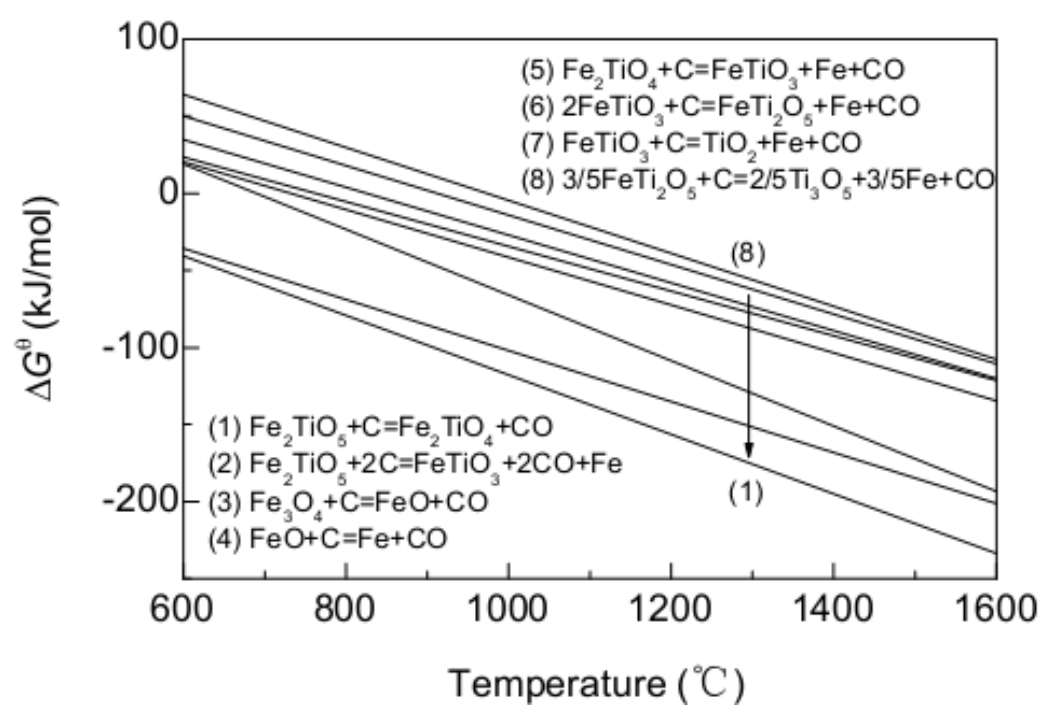

Fig.6 $\triangle \mathrm{G} \theta$ of the iron oxides and ilmenite reduced by $\mathbf{C}$ with increase of temperature

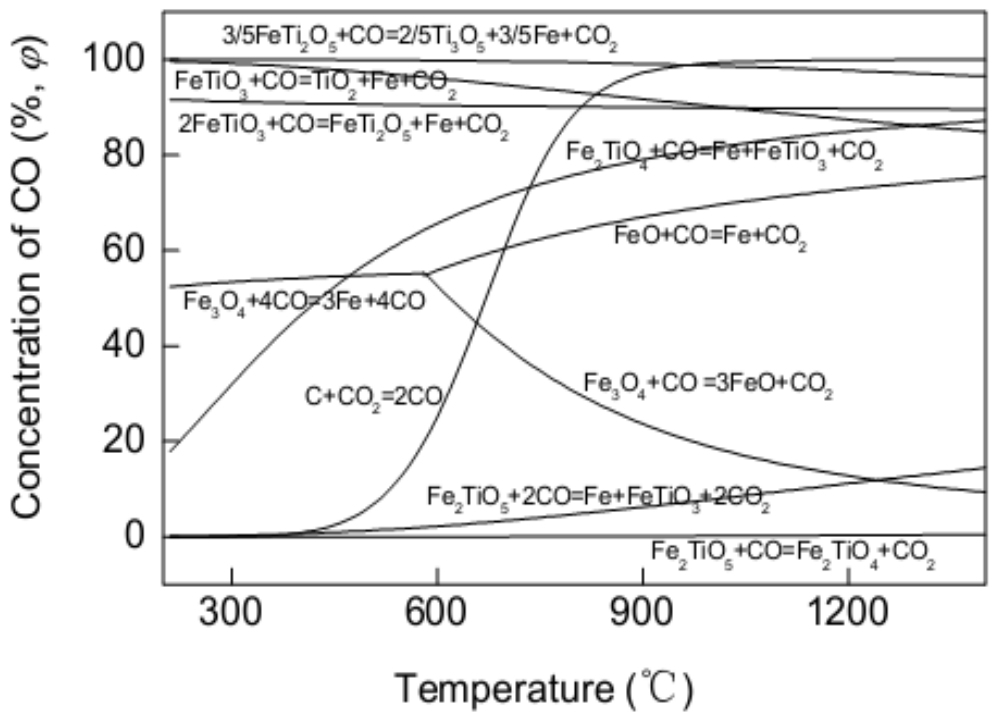

Fig.7 Phase equilibrium diagram of iron oxides and ilmenite reduced by $\mathrm{CO}$

In the temperature range of $1000^{\circ} \mathrm{C}-1150^{\circ} \mathrm{C}, \triangle \mathrm{G}^{\theta}$ of reaction equation (6) to (12) are greater than zero, thus, theoretically, these reactions were not be happened. At the same temperature range, $\triangle G^{\theta}$ 
of reaction equation (2), (3), (4), (13) and (14) are less than zero, so, theoretically, these reactions should happened.

In order to observe the reduction products in the temperature range of $800-1200^{\circ} \mathrm{C}$, the starting temperature of $800^{\circ} \mathrm{C}$ was chosen, which was used for phase analysis by XRD, as shown in Fig. $8^{[12]}$.

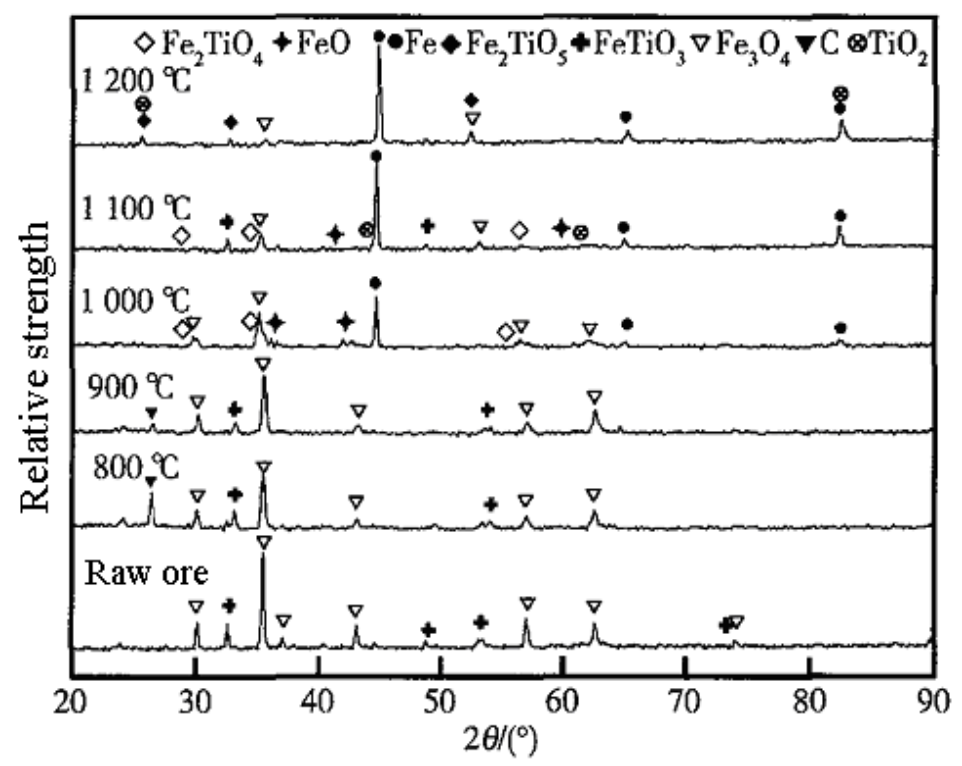

Fig.8 Phase analysis for reduction products by XRD

So, direct reduction progress of vanadium titano-magnetite concentrate is mainly combined two steps of direct reduction progress in the temperature range of $300-1150^{\circ} \mathrm{C}$ as follows ${ }^{[20]}$ :

$$
\begin{aligned}
\mathrm{Fe}_{2} \mathrm{O}_{3} \stackrel{(2)}{\rightarrow} \mathrm{Fe}_{3} \mathrm{O}_{4} \stackrel{(3)}{\rightarrow} \mathrm{FeO} \stackrel{(4)}{\rightarrow} \mathrm{Fe}, \\
\mathrm{Fe}_{2} \mathrm{O}_{3} \cdot \mathrm{TiO}_{2} \underset{(13)}{\longrightarrow} \mathrm{Fe}_{2} \mathrm{TiO}_{4} \underset{(14)}{\stackrel{\Gamma}{\longrightarrow}} \mathrm{FeTiO}_{3}
\end{aligned}
$$

As can be seen from the two direct reduction progresses, Figure 3 and Figure 5, it may be deduced that the thermal conductivity of vanadium titano-magnetite concentrate is roughly same as the common iron ore concentrate with the increase of temperature. But the direct reduction progress of vanadium titano-magnetite concentrate is much more different and complex than the common iron ore concentrate.

Figure 3 shows that change in thermal conductivity of vanadium titano-magnetite concentrate increases slowly $\left(0.06 \sim 0.12 \mathrm{~W} / \mathrm{m}^{\circ} \mathrm{C}\right)$ with in temperature range of $300-1000{ }^{\circ} \mathrm{C}$. It may be caused by the small changes of the thermal conductivity of different reduction products. When the temperature is higher than $1000^{\circ} \mathrm{C}$, the thermal conductivity raise sharply. It may generate enormous metallic iron, because the thermal conductivity of metallic iron is far more than the iron-oxides.

\section{Conclusions}

Following conclusions can be drawn from above conducted experiment.

(1) The change in law of thermal conductivity of vanadium titano-magnetite concentrate in direct reduction was roughly the same as the common iron ore concentrate.

(2) Thermal conductivity of vanadium titano-magnetite concentrate at different temperature in direct conduction was determined. It was found that thermal conductivity of vanadium-titanium magnetite carbon-containing pellets increase with increasing temperature.

(3) The measured values of the thermal conductivity roughly conform to the change trend of the thermal conductivity of theoretical analysis. The thermal conductivity change within $(0.06 \sim 0.12$ 
$\mathrm{W} / \mathrm{m}^{\circ} \mathrm{C}$ ) in the temperature range of $300^{\circ} \mathrm{C}-1000^{\circ} \mathrm{C}$. When the temperature is higher than $1000^{\circ} \mathrm{C}$, the thermal conductivity increase very rapidly.

Foundation Item: Item Sponsored by National Natural Science Foundation of China (51174122)

\section{References}

[1] W.L. Tennies, J. Lepinski, J.T. Kopfle, J. Ironmaking and Steelmaking, (1991) No.2, 36-42.

[2] B. Sarma, R.J. Fruehan, Ironmaking Conference Proceedings, ISS, Warrendale, PA, 57 (1998) No.2, 1537-1548.

[3] K. Fuji, H. Tanaka, T. Maki, Start-up Operations Report on the 2nd Commercial Fastmet Plant. J. Ironmaking Conference Proceedings, 2002, 705-712.

[4] T. HARADA, H. TANAKA, H. SUGTATSU, et al, J. Kobelco Technology Review, 24 (2001) No.10, 26-31.

[5] Y. Sawa, T. Yamamoto, K. Takeda, J. ISIJ Int., 41(Supplement) 2001, S17-S21.

[6] E. Park, O. Ostovski, J. ISIJ Int., 43 (2003) No.9, 1316-1325.

[7] E. Park, O. Ostovski, J. ISIJ Int., 44 (2004) No.1, 74-81.

[8] E. Park, O. Ostovski, J. ISIJ Int., 44 (2004) No.6, 999-1005.

[9] Q.Y. Tan, B. Chen, Y.S. Zhang, et al., J. Multipurpose Utilization of Mineral Resources, 2011 No.6, 6-9. (In Chinese)

[10] S.L. Yang, Metallurgical Industry Press, Beijing, China, 2012. (In Chinese)

[11] Q.S. He, IRON AND STEEL, 18 (1983) No.4, 1-6.

[12] D.S. Chen, B. Song, L.N. Wang, et al., J. Univ. Sci. Technol. Beijing, 33 (2011) No.11, 1331-1336.

[13] J.L. Zhang, X.D. Xing, M.M. Cao, et al., J. Iron and Steel Research, International, 20 (2013) No.2, 1-7.

[14] H. Li, Master Thesis, Xihua University, Chengdu, China, 2013. (In Chinese)

[15] Z.P. Yu, Y. Lu, Higher Education Press, 1995. (In Chinese)

[16] X.H. Wang, Metallurgical Industry Press, Beijing, China, 2010. (In Chinese)

[17] X.Z. Zhang, Metallurgical Industry Press, Beijing, China, 2004. (In Chinese)

[18] M. Takeda, T. Onishi, S. Nakakubo, et al., J. Material Transaction, 50 (2009) No.9, 2242-2246.

[19] S.L. Liu, PhD Thesis, Chongqing University, Chongqing, China, 2010. (In Chinese)

[20] S.Y. Chen, J. Tang, M.S. Chu, et al., J. Process Engineering, 13 (2013) No.2, 236-240. (In Chinese) 